\title{
Current Understandings of Plant Nonhost Resistance
}

\author{
Hyun-Ah Lee, Hye-Young Lee, Eunyoung Seo, Joohyun Lee, Saet-Byul Kim, Soohyun Oh, Eunbi Choi, \\ Eunhye Choi, So Eui Lee, and Doil Choi
}

Department of Plant Science, Plant Genomics and Breeding Institute, College of Agriculture and Life Sciences, Seoul National University, Seoul, 151-921, Republic of Korea

Accepted 6 December 2016.

\begin{abstract}
Nonhost resistance, a resistance of plant species against all nonadapted pathogens, is considered the most durable and efficient immune system of plants but yet remains elusive. The underlying mechanism of nonhost resistance has been investigated at multiple levels of plant defense for several decades. In this review, we have comprehensively surveyed the latest literature on nonhost resistance in terms of preinvasion, metabolic defense, pattern-triggered immunity, effector-triggered immunity, defense signaling, and possible application in crop protection. Overall, we summarize the current understanding of nonhost resistance mechanisms. Pre- and postinvasion is not much deviated from the knowledge on host resistance, except for a few specific cases. Further insights on the roles of the pattern recognition receptor gene family, multiple interactions between effectors from nonadapted pathogen and plant factors, and plant secondary metabolites in host range determination could expand our knowledge on nonhost resistance and provide efficient tools for future crop protection using combinational biotechnology approaches.
\end{abstract}

Unlike mammals, plants are sessile and have no adaptive immune system. Although numerous pathogens attack plants in nature, most plants are resistant to most pathogens. This phenomenon, termed nonhost resistance (NHR), defines the resistance of an entire plant species against a specific parasite or pathogen (Heath 2000). In other words, NHR is the plant resistance at species-specific level and the most durable resistance of plants. Due to its durability, NHR has attracted increasing attention as a valuable strategy for improving crop resistance. However, interspecific sterility has often hindered the elucidation of the genetic basis of NHR, slowing down its deployment in the field. The mechanism of NHR is currently considered to rely on a complex combination of constitutive and induced defense components (Fan and Doerner 2012; Lee et al. 2014; Niks and Marcel 2009).

Plants possess an elaborate suite of defense components to protect themselves against pathogen infection. Encounters between plants and pathogens occur at the cuticle and cell-wall layer, which act as a physical barrier (Tucker and Talbot 2001). Plants also establish a chemical barrier by accumulating a

H.-A. Lee and H.-Y. Lee contributed equally to this work.

Corresponding author: D. Choi; E-mail: doil@snu.ac.kr; Fax: +82-2-873-2056.

(c) (i) () $\odot$ Copyright (C) 2017 The Author(s) This is an open access article distributed under the CC BY-NC-ND 4.0 International license. diverse array of secondary metabolites constitutively or rapidly produced upon pathogen infection with toxic or inhibitory effects (VanEtten et al. 1994). In addition, plants can recognize invading pathogens using membrane or cytoplasmic receptors that induce two layers of defense response (Dodds and Rathjen 2010). First, surface-localized receptors can perceive nonself or damaged-self signal, in the form of conserved pathogen structures called pathogen-associated molecular patterns (PAMPs) or damage-associated molecular patterns (DAMPs) released during alteration of host cell integrity (Raaymakers and Van den Ackerveken 2016). These patterns are recognized via pattern-recognition receptors (PRRs), mainly located at the plasma membrane, that induce a first rise in plant defense level generally termed PAMP-triggered immunity (PTI) (Zipfel 2009). To suppress PTI and dampen host defense, successful pathogens secrete a number of effector proteins into host cells (Dodds and Rathjen 2010). In turn, plants induce a second rise in defense level, designated effector-triggered immunity (ETI), via recognition of effectors by intracellular immune receptors called resistance $(\mathrm{R})$ proteins, which often belong to the nucleotide-binding domain and leucine-rich repeat-containing (NLR) family (Maekawa et al. 2011). ETI is typically accompanied by a hypersensitive response (HR), a rapid programmed cell death at the infection site to restrict the spread of pathogens (Jones and Dangl 2006).

From numerous studies using various approaches from cytology to omics techniques over the last decades, it appears that the multiple defense components are involved in NHR in a complex manner. Most of the cytological observations of pathogen penetration on nonhost plants were performed in the 1970s. These initial observations show that often nonadapted pathogens stop growing during the very early stage of infection and that several nonhost species exhibit HR cell death at the infection site (Crute and Johnson 1976; Heath 1974; Mendgen 1978). Later, it was suggested that NHR consists of complex defense factors including a physical or chemical barrier and an active response (Heath 1981). Callose and phytoalexin accumulation around the infection sites were observed and quantified in nonhost plants (Fink et al. 1990; Jahnen and Hahlbrock 1988; Perumalla and Heath 1989). Transposon mutagenesis further allowed the identification of pathogenicity factors that elicit HR on nonhost plants (Lindgren et al. 1986; Whalen et al. 1988). Concomitantly, the durability of NHR has been recognized as an important strategy to improve crop resistance (Niks 1987). Genes involved in NHR were identified, in the 1990s, from both plant (polygalacturonase) and pathogen (INF1) (Allen 1991; Fillingham et al. 1992; Kamoun et al. 1998). Participation of both PTI and ETI to NHR emerged from identification of Arabidopsis PRR EFR and of two NLR genes, 
including maize Rxol and Arabidopsis WRR4 (Borhan et al. 2010; Lacombe et al. 2010; Zhao et al. 2004b). Later, with respect to defense signaling, the concept that NHR shares signaling components with host resistance has been supported by transcriptional and metabolite profiling approaches (Gill et al. 2015; Ishiga et al. 2015; Kanzaki et al. 2003; Peart et al. 2002; Zellerhoff et al. 2010). Hence, there has been considerable progress toward unraveling NHR. Here, we comprehensively review the multiple defense components involved in NHR and summarize our current knowledge and prospects on this valuable form of plant resistance.

\section{The role of preinvasion resistance.}

The plant epidermis is generally protected by a waxy cuticle and the plant cell wall. Together, they form a physical barrier that pathogens have to breach in order to infect plants. The preinvasive penetration barrier is the first line of plant defense against pathogen attacks and is considered an important factor in NHR.

Nonadapted pathogens normally fail to penetrate nonhost plant cells when blocked by preformed physical barriers present on the plant surface (Kamoun 2001; Pinosa et al. 2013). Components of leaf waxes can act as an inductive cue for pathogens to develop infection structures and lack of appropriate signals in plants contributes to NHR. Colletotrichum gloeosporioides that successfully induces appressorium on host avocado cannot induce differentiation of appressorium on nonhost plants (Podila et al. 1993). This is the result of difference in fatty alcohol composition of waxes, as nonhost plants contain a higher content of alcohols with longer chains compared with host plants. Similarly, $\mathrm{C}_{26}$ aldehyde presence in wax of host barley cuticle plays an important role in appressorium differentiation of Blumeria graminis f. sp. hordei (Tsuba et al. 2002). Nonhost cabbage cuticle has higher $C_{28}$ and $C_{30}$ aldehyde contents, which are less efficient to trigger $B$. graminis appressorium differentiation. Another component of preinvasive defense is the alfalfa IRGI (Inhibitor of rust germ tube differentiation 1) gene that encodes a $\mathrm{C}_{2} \mathrm{H}_{2}$ zinc finger transcription factor now called PALM1 (Palmate-like pentafoliata1) and regulates the expression of genes involved in wax biosynthesis. Reduction of surface hydrophobicity due to altered proportion of primary alcohol in irgl mutant cuticle inhibits the differentiation of prepenetration structures of nonadapted rust pathogens (Uppalapati et al. 2012). Barley epicuticular wax biosynthetic gene $C Y P 96 B 22$ also functions in penetration resistance of nonadapted Magnaporthe oryzae (Delventhal et al. 2014). Of note, in addition to leaf waxes, membrane lipid phosphatic acid is also associated with Arabidopsis NHR to pea fungal pathogen Erysiphe pisi (Pinosa et al. 2013).

Beside preformed structural defenses, induced preinvasive defense responses have an important role in NHR. During the early phase of invasion, polarized rearrangement of microfilaments and microtubules is triggered by attempted pathogen penetration and mediates defense-related responses, such as massive cytoplasmic aggregation and cell-wall apposition at the infection site (Kobayashi et al. 1997a; Takemoto et al. 2003). Evidence suggests that nonadapted pathogen invasion is hindered by these cytoskeleton and wall rearrangements. For instance, treatment with actin polymerization inhibitor cytochalasin allows Erysiphe pisi to penetrate epidermal cells of nonhost plants and to form haustoria (Kobayashi et al. 1997b). The level of actin depolymerization is, indeed, correlated with the penetration efficiency of several nonadapted pathogens, including Colletotrichum lagenarium and Alternaria alternata (Kobayashi et al. 1997a). In Arabidopsis, nonadapted pathogens, including wheat powdery mildew B. graminis f. sp. tritici and Colletotrichum species, also penetrate epidermal cells and develop haustoria under the cytochalasin treatment (Shimada et al. 2006). Additionally, adhesion between plasma membrane and cell wall is important for penetration resistance. Exogenous application of peptides carrying an Arg-Gly-Asp (RGD) motif of mammalian plasma membranebound receptors causes a loss of connection between plasma membrane and cell wall in cowpea, which results in downregulation of the cell wall-associated defense response and increased penetration of nonadapted fungal pathogen (Mellersh and Heath 2001).

Taken together, cell wall-associated defense response plays an important role in NHR as well as in basal resistance. In contrast to adapted pathogens that suppress wall defenses and successfully penetrate the host cells, nonadapted pathogens might not have evolved a suppressor of preinvasion resistance.

\section{The role of metabolic defense.}

Plants produce secondary metabolites as chemical barriers to defend themselves against invading pathogens (Hölscher et al. 2014; Lei et al. 2014). This diverse array of antimicrobial compounds can largely be divided into two groups: i) phytoanticipins, a group of constitutive secondary metabolites and ii) phytoalexins that are de novo synthesized and rapidly accumulated upon pathogen infection (Dixon 2001; Hammerschmidt 1999; VanEtten et al. 1994). Extensive studies about defensive secondary metabolites support the determinant role in resistance for antimicrobial compounds in compatible host-pathogen interactions (Ahuja et al. 2012). Antimicrobial phytochemicals are toxic for a broad range of fungi and detoxification mechanisms are required to establish pathogenicity and virulence. For example, in tomato, the phytoanticipin $\alpha$-tomatine binds to sterols in fungal membrane, resulting in disruption of membrane integrity of pathogens and enhanced resistance (Bangham and Horne 1962; Roddick 1976; Schulz and Sander 1957). However, several adapted pathogens overcome $\alpha$-tomatine by producing tomatinase, a glycosyl hydrolase. Tomatinase-deficient mutants of Cladosporium fulvum and Fusarium oxysporum f. sp. lycopercisi are less virulent than the wild-type strain (Ökmen et al. 2013; Pareja-Jaime et al. 2008; Roldán-Arjona et al. 1999; Sandrock and VanEtten 1998).

The causal agent of take-all disease of wheat, Gaeumannomyces graminis var. tritici, cannot cause disease on nonhost oats due to its susceptibility to the phytoanticipin avenacin. However, Gaeumannomyces graminis var. avenae, which produces avenacinase, overcomes the avenacin-mediated growth inhibition and causes disease on oats (Bowyer et al. 1995; Osbourn et al. 1994; Papadopoulou et al. 1999). Similarly, preformed sulforaphane plays a determinant role in NHR of Arabidopsis to bacteria Pseudomonas syringae (Fan et al. 2011). Multiple sax genes of adapted $P$. syringae pv. maculicola function in detoxification and efflux of sulforaphane. Nonadapted $P$. syringae strains transformed with $\operatorname{sax} C A B$ genes can overcome Arabidopsis NHR. In Amaranthus gangeticus, accumulation of nicotinamide in roots prevents colonization by nonadapted fungal pathogen Aphanomycese cochliodes (Islam et al. 2004).

Unlike constitutively produced phytoanticipins, phytoalexin synthesis is triggered by recognition of elicitors, PAMPs or DAMPs, or effectors and is often mediated by activation of the mitogen-activated protein kinase (MAPK) pathway (Graham et al. 1990; Kishi-Kaboshi et al. 2010; Raaymakers and Van den Ackerveken 2016; Umemoto et al. 1997). Arabidopsis oligogalacturonides released by polygalacturonase activity of Botrytis cinerea are a class of DAMPs that induce production of phytoalexin camalexin via activation of MAPK cascades and phosphorylation of WRKY33 (Ferrari et al. 2007; Mao et al. 2011; Ren et al. 2008). Phytoalexins are also linked to other 
defense signaling mechanisms. For instance, indole glucosinolate is required for callose deposition induced by flagellin elicitor peptide flg22, which plays a role as an effective physical barrier at the sites of pathogen attack (Clay et al. 2009; Luna et al. 2011). Phytohormones including ethylene (ET), jasmonate (JA), auxin, and cytokinin also control the synthesis of phytoalexins (Grosskinsky et al. 2011; Huffaker et al. 2011; Matsukawa et al. 2013; Robert-Seilaniantz et al. 2011). In particular, JA acts as a positive regulator and induces secondary metabolite accumulation through transcriptional regulation in a wide range of plant species (De Geyter et al. 2012).

Similarly to host resistance, pathogen recognition in nonhost plants elicits phytoalexin accumulation. Alfalfa infected with Asian soybean rust mounts a localized cell death in penetrated epidermal cells and induces the synthesis of medicarpin and its intermediate metabolites that suppress rust appressorium formation (Ishiga et al. 2015). The oligopeptide elicitor Pep-13, highly conserved among the oomycete genus Phytophthora, triggers transcriptional reprogramming and accumulation of phytoalexin furanocoumarins in nonhost parsley (Brunner et al. 2002; Nürnberger et al. 1994). In addition to Pep-13, necrosisinducing Phytophthora protein 1 (NPP1) elicits HR-like cell death and causes responses similar to Pep-13 in parsley, indicating that phytoalexin induction is associated with recognition of multiple elicitors in nonhost (Hahlbrock et al. 2003). Recognition of necrotrophic effector ToxA by nonhost wheat results in cell death and serotonin accumulation, which inhibits sporulation of Stagonospora nodorum (Du Fall and Solomon 2013). In Arabidopsis, tryptophan (Trp)-derived indole glucosinolates and camalexin are involved in NHR against biotroph powdery mildew and hemibiotroph $C$. gloeosporioides (Hiruma et al. 2013; Lipka et al. 2005; Sanchez-Vallet et al. 2010). PENETRATION2 (PEN2) encodes a myrosinase involved in hydrolysis of indole glucosinolates (Lipka et al. 2005). Arabidopsis pen 2 mutants deficient in accumulation of an indole and a cysteine metabolite allow frequent initiation of invasive growth of broadspectrum nonadapted pathogens, including Phytophthora infestans, B. graminis f. sp. hordei, and Magnaporthe oryzae (Bednarek et al. 2009; Lipka et al. 2005; Maeda et al. 2009). In spite of enhanced entry rates of nonadapted pathogens in pen 2 mutants, postinvasive resistance associated with cell death blocks further infection, suggesting the involvement of the other defense components in NHR. In the interaction between Arabidopsis and C. gloeosporioides, glutathione with Trp-derived metabolites is required for pre- and postinvasive resistance (Hiruma et al. 2013). Mutants defective in both glutathione synthesis and Trp metabolism allow enhanced invasive hyphae expansion of nonadapted pathogen C. gloeosporioides. Furthermore, Arabidopsis RRS1/RPS4mediated resistance to the adapted pathogen $C$. higginisianum is compromised in these mutants, further supporting the idea that defense compounds are shared between host and nonhost resistance.

Plants have evolved lineage-specific antimicrobial compounds as a consequence of the coevolutionary arms race and adapted pathogens can cause disease by detoxification of these compounds (Kliebenstein 2012; Kroymann 2011). Probably, nonadapted pathogens had no chance to encounter defense metabolites produced by nonhost plants and to prepare adequate weapons to overcome the obstacles, as illustrated by the higher sensitivity of Phytophthora infestans to capsidiol induced in nonhost pepper compared with the adapted pathogen Phytophthora capsici (Giannakopoulou et al. 2014; Jones et al. 1975). Thus, adaptation of pathogens to specific antimicrobial compounds is one of the determinants of NHR and comprehensive analysis of the role of chemical barriers in relation to other defense components could improve our understanding of the NHR mechanisms.

\section{The role of PTI.}

Plant cells have the ability to discriminate self from nonself and activate defense signaling in response to attempted pathogen invasion (Nürnberger and Brunner 2002). Sensing of potential invaders is mediated by membrane-localized PRRs. In adapted hostpathogen interactions, several PAMPs, such as flagellin, chitin, lipopolysaccharide, or extracellular adenosine triphosphate, have been identified and their mode of recognition has been characterized (Couto and Zipfel 2016). As PAMPs are highly conserved and functionally essential for microbe fitness, PAMP recognition and PTI are an efficient component of NHR.

The best-studied PAMP playing a role in NHR is the bacterial flagellin, the flagella building block (Hayashi et al. 2001). $P$. syringae pv. tabaci mutants deficient for flagellin production cause disease symptoms on nonhost Arabidopsis and tomato (Li et al. 2005; Taguchi et al. 2003). Conversely, the P. syringae pv. tabaci $\triangle$ fliD mutant, which secretes large amounts of flagellin monomer, induces HR cell death on the nonhost tomato (Shimizu et al. 2003). However, flagellin of an adapted $P$. syringae strain does not induce HR on tobacco, in spite of identical amino acid sequence with flagellin of nonadapted $P$. syringae pv. glycinea, which suggests the role of posttranslational modification of flagellin in recognition by nonhost plants (Taguchi et al. 2003; Takeuchi et al. 2003). Flagellin glycosylation that is indispensable for flagella stabilization is ubiquitous in most of phytopathogenic bacteria and plays an important role in bacterial virulence (Ichinose et al. 2013; Taguchi et al. 2008, 2009). Glycosyltransferase-deficient mutants of $P$. syringae pv. glycinea can multiply in nonhost Arabidopsis and tobacco while losing pathogenicity on host plants (Ishiga et al. 2005; Takeuchi et al. 2003). The findings that nonglycosylated flagellin induces a higher level of defense responses on host plants than glycosylated flagellin suggest that pathogens might have evolved to evade recognition by host plants through posttranslational modification (Taguchi et al. 2009). The modified PAMPs to increase virulence in host plants might enable pathogens to be recognized by nonhost plants.

On the other hand, the flagellin receptor Flagellin-sensing 2 (FLS2) also mediates NHR (Zipfel et al. 2004). Genetic screening of Arabidopsis natural variation for resistance to nonadapted bacteria reveals that FLS2 confers resistance to the bean pathogen $P$. syringae pv. phaseolicola (Forsyth et al. 2010). Moreover, Arabidopsis fls 2 mutants and FLS2-silenced Nicotiana benthamiana plants show enhanced susceptibility to nonadapted P. syringae strains (Hann and Rathjen 2007). Nonhost plants also induce downstream signaling upon flagellin perception. The flg22 strongly induces transcription of NONHOSTl (NHOl) encoding a glycerol kinase that is required for Arabidopsis NHR against nonadapted $P$. syringae pv phaseolicola, whereas the adapted $P$. syringae strain only transiently induces $\mathrm{NHOl}$ expression $(\mathrm{Li}$ et al. 2005; Lu et al. 2001). The induction of $\mathrm{NHOl}$ is presumably essential because Arabidopsis plants overexpressing $\mathrm{NHOl}$ exhibit enhanced resistance to adapted $P$. syringae pv. tomato DC3000 (Kang et al. 2003). These results suggest that nonhost plants could trigger an immune response by PAMP recognition similarly as during host resistance.

Based on the evolutionary model of NHR, the relative contribution of PTI to NHR increases in nonhost species with a distant evolutionary relationship from the host due to lack of effector targets to suppress defense response (Schulze-Lefert and Panstruga 2011). Interfamily or interspecies transfer of PRRs from nonhost plants expands the recognition specificity, as shown by Arabidopsis EFR (EF-Tu receptor) transfer to tomato and wild potato ELR (elicitor response) transfer to Solanum tuberosum (Du et al. 2015; Lacombe et al. 2010). Thus, PTI in NHR as well as in host resistance provides broad-spectrum resistance to phytopathogens. 


\section{The role of ETI.}

ETI is one of the major components of host resistance in plants (Cui et al. 2015). It is activated by direct or indirect interaction between one or more pathogen effectors and one or more plant R proteins, often resulting in HR. Previous studies proposed that NHR may be partially mediated by effectors and $R$ genes even though specific roles and mechanisms of ETI in NHR remain elusive (Stam et al. 2014).

Numerous cases of the effector recognition in nonhost plants have been reported (Table 1). For example, $P$. syringae pv. tomato avrA homolog, $P$. syringae pv. phaseolicola avrPphD, and Xanthomonas. oryzae pv. oryzicola AvrRxo1 induce HR on their respective nonhost plants (Arnold et al. 2001; Kobayashi et al. 1989; Liu et al. 2014; Zhao et al. 2004b). Similarly, Bremia lactucae effector BLG01 carrying a GKLR variant of the RXLR translocation motif induces HR in a backcross inbred line of nonhost Lactuca saligna (Jeuken and Lindhout. 2002; Stassen et al. 2013). In addition, a recent study reported that several RXLR effectors of Phytophthora infestans trigger HR in nonhost pepper accessions, suggesting multiple interaction between effectors and putative target genes in NHR (Lee et al. 2014). Meanwhile, some effectors have been suggested as major determinants of host range. P. syringae pv. tomato DC3000 HopQ1 deletion mutant can cause bacterial speck symptoms in nonhost $N$. benthamiana (Wei et al. 2007). Similarly, mutation of HopAS1 from P. syringae pv. tomato T1 confers enhanced virulence in nonhost Arabidopsis and reduced virulence of host tomato (Sohn et al. 2012). Therefore, effectors might be involved in limitation of host range and NHR.

The HR triggered by effectors in certain nonhost plants probably results from the activation of one or more $R$ genes and subsequent defense signaling, as observed in compatible hostpathogen interactions. Genetic analysis reveals that necrotic phenotypes induced by AvrRPS4 and HopK1 from $P$. syringae cosegregate with clusters of RGC4 (Resistance Gene Candidate4) homologs encoding NLRs in nonhost lettuce (Wroblewski et al. 2009). In addition, maize NLR Rxo1 recognizes avrRxo1 from $X$. oryzae pv. oryzicola, which causes bacterial leaf streak disease in rice (Zhao et al. 2004a, 2004b, 2005). In Arabidopsis, WRR4 encoding a toll/interleukin1-receptor-NLR protein confers resistance against Albugo candida, which is a nonadapted pathogen indicating that $R$ genes are indeed involved in NHR, although the corresponding effector remains to be elucidated (Borhan et al. 2008, 2010). By contrast, single mutants carrying nonfunctional copies of those NLRs still show resistance to nonadapted pathogens, which opens the possibility of multiple $\mathrm{R}$ protein-effector interactions in NHR (Borhan et al. 2008; Zhao et al. 2005). Finally, there are more unidentified $R$ genes that cosegregate with HR triggered by effectors in nonhost plants (Vega-Arreguín et al. 2014; Whalen et al. 1988). This further highlights the importance of endogenous $R$ genes and $R$ gene-mediated responses in NHR.

Plants and pathogens are coevolving in a never-ending arms race. A recent concept of NHR in evolutionary aspects suggests that relative contribution of ETI mediated by NLR proteins increases in the case of close evolutionary relationship between host and nonhost plant (Schulze-Lefert and Panstruga 2011). Identification of one or more plant factors recognizing one or more effectors from nonadapted pathogens and elucidation of ETI mechanisms in NHR may shed light on how NHR is established.

\section{Defense signaling in NHR.}

After perception of pathogens, plants activate complex signaling including oxidative burst, MAPK cascade, hormone biosynthesis, and transcriptional reprogramming (Boller and Felix 2009; Tsuda and Katagiri 2010). On the basis of nonhost defense responses from several pathosystems, accumulation of reactive oxygen species (ROS), induction of defense-related genes, salicylic acid (SA) and JA production, and callose deposition are commonly associated with NHR, regardless of HR cell-death symptoms, suggesting overlaps with the host defense response (An and Mou 2012; Cheng et al. 2012; Narusaka et al. 2005; Trujillo et al. 2004; Yun et al. 2003; Zhang et al. 2011).

There are some evidences that PRR- or $R$ gene-mediated signaling machinery used by host resistance also function in NHR. The PRR FLS2 forms heteromeric complexes with coreceptors BAK1 (BRI1-associated receptor kinase1) or related SERKs (somatic embryogenesis receptor kinase) (Heese et al. 2007; Chinchilla et al. 2007; Roux et al. 2011). BAK1 transcript accumulation in Arabidopsis increases more than twofold in the presence of nonadapted $P$. syringae pv. phaseolicola but decreases during host interaction (Kemmerling et al. 2007). Arabidopsis bakl mutants are susceptible to nonadapted $P$. syringae pv. tabaci 6605 and Alternaria brassicicola (Kemmerling et al. 2007; Roux et al. 2011). Similarly, silencing of $B A K 1$ in $N$. benthamiana

Table 1. Effectors and nucleotide-binding domain and leucine-rich repeat (NLR) proteins in nonhost interactions

\begin{tabular}{|c|c|c|c|c|}
\hline Name & Pathogen species & Nonhost & Feature $^{\mathrm{a}}$ & References \\
\hline \multicolumn{5}{|l|}{ Effectors } \\
\hline avrRxv & $\begin{array}{l}\text { Xanthomonas campestris pv. vesicatoria } \\
\text { tomato race } 1\end{array}$ & Common bean & $\begin{array}{l}\text { Induce } \mathrm{HR} \text {, cosegregate } \\
\text { with } R x v\end{array}$ & Whalen et al. 1988 \\
\hline avrA homolog & P. syringae pv. tomato & Soybean & Induce HR & Kobayashi et al. 1989 \\
\hline avrPphD & P. syringae pv. phaseolicola & Pea & Induce HR & Arnold et al. 2001 \\
\hline avrRxo1 & X. oryzae pv. oryzicola & Maize & $\begin{array}{l}\text { Induce HR, cosegregate } \\
\text { with NLR (Rxol) }\end{array}$ & Zhao et al. 2004a, 2004b \\
\hline HopQ1-1 & P. syringae pv. tomato DC 3000 & Nicotiana benthamiana & Induce HR & Wei et al. 2007 \\
\hline AvrRPS4 & P. syringae pv. phaseolicola $1148 \mathrm{~A}$ & Lettuce & $\begin{array}{l}\text { Induce HR, cosegregate } \\
\text { with NLR locus }(R G C 4)\end{array}$ & Wroblewski et al. 2009 \\
\hline HopK1 & P. syringae pv. tomato DC 3000 & Lettuce & $\begin{array}{l}\text { Induce HR, cosegregate } \\
\text { with NLR locus }(R G C 4)\end{array}$ & Wroblewski et al. 2009 \\
\hline BLG01 & Bremia lactucae & Lactuca saligna & Induce HR & Stassen et al. 2013 \\
\hline avrRxo1 & X. oryzae pv. oryzicola & Nicotiana benthamiana & Induce HR & Liu et al. 2014 \\
\hline PcAvr3a1 & Phytophthora capsici & Tobacco & Induce HR & Vega-Arreguín et al. 2014 \\
\hline PexRD8 & Phytophthora infestans & Hot pepper & Induce HR & Lee et al. 2014 \\
\hline Avrblb2 & Phytophthora infestans & Hot pepper & Induce HR & Lee et al. 2014 \\
\hline HopAS1 & P. syringae pv. tomato $\mathrm{T} 1$ & Arabidopsis & Induce HR & Sohn et al. 2012 \\
\hline \multicolumn{5}{|l|}{ NLRs } \\
\hline Rxo1 & X. oryzae pv. oryzicola & Maize & Recognizes avrRxo1 & Zhao et al. 2005 \\
\hline WRR4 & Albugo candida & Arabidopsis & & Borhan et al. 2008, 2010 \\
\hline
\end{tabular}

\footnotetext{
${ }^{\mathrm{a}} \mathrm{HR}=$ hypersensitive response.
} 
enhances the growth of nonadapted $P$. syringae pv. tomato DC3000 (Heese et al. 2007). In $R$ gene-mediated signaling, a conserved chaperone complex comprising HSP90, SGT1, and RAR1 is required for activation and stabilization of $\mathrm{R}$ proteins (Kadota et al. 2010). Silencing of HSP90 or SGTl in $N$. benthamiana compromises NHR to nonadapted pathogens such as $P$. cichorii or $X$. axonopodis pv. vesicatoria (Kanzaki et al. 2003; Peart et al. 2002). EDS1 (Enhanced disease susceptibility 1 ) is an essential regulator of $R$ gene-mediated signaling. Mutation in Arabidopsis EDS1 enhances susceptibility to nonadapted Albugo candida and Erwinia amylovora (Moreau et al. 2012; Parker et al. 1996). In addition, HR triggered by conidia of nonadapted wheat powdery mildew (B. graminis f. sp. tritici) is significantly reduced in eds 1 mutants (Yun et al. 2003). In the nonhost ArabidopsisBlumeria pathosystem, the mutation of EDS1 interactors, such as PAD4 and SAG101 in the pen 2 mutant, caused breakdown of NHR (Lipka et al. 2005). Further, one of the earliest downstream signaling events upon pathogen perception is activation of MAPKs that act as a central hub in subsequent defense responses, such as ROS generation, defense-gene activation, and hormone biosynthesis (Meng and Zhang 2013). As MAPK cascades are highly conserved among eukaryotes, signal transduction in NHR is also mediated through MAPKs. Silencing of $N b M K K 1, N b S I P K$, or $N b W I P K$ compromises NHR of N. benthamiana to P. cichorii (Sharma et al. 2003; Takahashi et al. 2007). Conversely, adapted $P$. syringae strains carry effectors such as AvrPto, AvrPtoB, or HopAl1 to suppress MAPK cascade in host plants. Moreover, ectopic expression of AvrPto promotes the growth of two nonadapted bacterial pathogens in Arabidopsis, suggesting that effectors that have been evolved to suppress defense response could play a pivotal role for pathogens to overcome NHR (He et al. 2006; Zhang et al. 2007).

Other early responses of plants upon pathogen perception include calcium influx and ROS production, which both act as secondary messengers (Boller and Felix 2009). Increased cytosolic calcium level leads to activation of calcium-dependent protein kinases and NADPH oxidase RbohD responsible for the rapid production of ROS in Arabidopsis, which suggests the mechanistic link between calcium and ROS signaling (Ogasawara et al. 2008; Ranf et al. 2011; Segonzac and Zipfel 2011). ROS also mediates cellular signaling associated with defense-related gene expression, HR, and phytoalexin production (O'Brien et al. 2012). However, only a few studies have investigated the role of ubiquitous messenger $\mathrm{Ca}^{2+}$ and $\mathrm{ROS}$ in NHR. In $N$. benthamiana, calreticulin that functions in $\mathrm{Ca}^{2+}$ binding and storage is essential for NHR to $X$. oryzae pv. oryzae (Li et al. 2012). Likewise, the mutation of calcium sensor CaM7 in Arabidopsis compromises NHR to Asian soybean rust (Campe et al. 2016). On another hand, a hydrogen peroxide burst is observed at the site of cell-wall apposition in barley upon tentative infection by nonadapted wheat powdery mildew infection (Hückelhoven et al. 2001). In N. benthamiana, silencing of glycolate oxidase (Gox), which produces hydrogen peroxide in peroxisome, compromises NHR to $P$. syringae pvs. tomato and glycinea as well as Pto-AvrPto interaction (Rojas et al. 2012b). Arabidopsis gox mutants also display enhanced susceptibility to a nonadapted strain of $P$. syringae, concomitantly to reduced accumulation of hydrogen peroxide and compromised HR. In addition, treatment with flavodoxin, which prevents ROS formation in plastids, reduces HR and ROS accumulation in tobacco, upon inoculation with nonadapted $X$. campestris pv. vesicatoria (Zurbriggen et al. 2009). These results highlight that nonhost plants employ common factors of host resistance in an early stage of signal transduction after receptor-dependent pathogen perception.
Pathogen perception activates signaling for hormone biosynthesis. The plant hormones ET, JA, and SA play an important role as secondary messengers of plant defense response (Meng and Zhang 2013). Accumulating evidence shows that defense hormones also contribute to NHR. Tobacco expressing the Arabidopsis etrl-1 gene shows ET insensitivity and loses NHR against Pythium sylvaticum, demonstrating a role for ET in NHR (Knoester et al. 1998). Nonadapted rust fungi, including Uromyces vignae and $U$. appendiculatus, produce longer infection hyphae in an Arabidopsis sid2 mutant deficient for SA biosynthesis and in $N a h G$-expressing plants in which SA is degraded to catechol (Mellersh and Heath 2003). In Arabidopsis, Plant defensin 1.2 (PDF1.2), a marker gene of the JA/ET signaling pathway, is induced upon inoculation with nonadapted barley powdery mildew, whereas host interaction between Arabidopsis and Erysiphe cichoracacearum only triggers a moderate induction of PDF1.2 expression (Zimmerli et al. 2004). In spite of the effect of defense hormones in plant resistance, most of the single mutants related to hormone signaling are not significantly affected in NHR (Ham et al. 2007; Mishina and Zeier 2007). This accounts for the complex network of defense hormone signaling and multiple layers of NHR.

Comparative analysis of transcription profiles following inoculation of adapted and nonadapted pathogens reveals that plants activate fundamentally similar programs but that strong transcriptional activation or repression occurs earlier in nonhost interaction (Zellerhoff et al. 2010; Zimmerli et al. 2004). According to quantitative analysis of transcript abundance, most of the differentially expressed genes in nonhost interactions are related to biotic or abiotic stress, the secondary metabolic pathway, or transcription factors, including APETALA2/ET response element binding factor (ERF) (Daurelio et al. 2013; Moreau et al. 2012; Zellerhoff et al. 2010). Transcription factors modulate different sets of defense-related genes and participate in NHR as well as in host resistance. $N b C D 1$, encoding an ERF, is induced by nonadapted $P$. cichorii and silencing of $N b C D 1$ compromises NHR of $N$. benthamiana to $P$. cichorii (Nasir et al. 2005). Similarly, NAC transcription factor ATAF1 contributes to penetration resistance of Arabidopsis against the nonadapted B. graminis f. sp. hordei via suppression of abscisic acid biosynthesis and signaling (Jensen et al. 2008; Wang et al. 2009). In addition, calmodulin-binding transcription activators negatively regulate NHR to bacterial pathogens, by downregulation of target genes including EDS1, CBP60G, and NDR1 and by subsequent ROS accumulation suppression (Rahman et al. 2016). Changes of defense-related gene expression and transcription factor activities could amplify defense signals in a positive feedback loop to enhance NHR.

It is interesting to note that various accessions of a nonhost species show different responses to the same nonadapted pathogen or its effectors (Lee et al. 2014; Mellersh and Heath 2001; Wroblewski et al. 2009). Given the overlaps of defense signaling components in host and nonhost resistance, identification of nonhost receptors that mediate pathogen perception and induce defense response could be a vital element to utilize NHR mechanisms for crop improvement.

\section{Miscellaneous factors in NHR.}

Last but not least, there are reports on involvement of unexpected plant components in NHR. For example, sphingolipids are membrane components that are involved in signal transduction for cellular homeostasis and stress responses such as apoptosis. Serine palmitoyltransferases, which catalyze the first step of sphingolipid biosynthesis, comprise two different subunits, LCB1 and LCB2. N. benthamiana NHR to P. cichorii is compromised in NbLCB1- and NbLCB2-silenced plants, suggesting involvement of sphingolipids in NHR (Takahashi 
et al. 2009). A similar example is reported for membraneattached protein, such as the small GTPase (Ras) that regulate diverse processes including vesicular trafficking (Rojas et al. 2012a). Silencing of ADP ribosylation factor 1 (ARF1), a member of the conserved Ras superfamily, enhances $P$. cichorii growth on nonhost $N$. benthamiana (Coemans et al. 2008). In addition, silencing of RPL12 and RPL19, encoding ribosomal proteins in $N$. benthamiana, leads to delay of HR and enhances bacterial growth of nonadapted pathogens ( $P$. syringae pv. tomato T1, $P$. syringae pv. glycinea, and $X$. campestris pv. vesicatoria) (Nagaraj et al. 2015). Moreover, overexpression of barley BI-1 (Bax inhibitor-1), which suppresses programmed cell death, allows nonadapted $B$. graminis f. sp. hordei to penetrate the barley epidermal cells, indicating a connection between cell-death regulation and NHR (Eichmann et al. 2004). Furthermore, alteration of chromatin structures via DNA damage and nuclear protein modifications affects transcription initiation of pathogenesis-related $(P R)$ genes (Hadwiger 2015). DNase released from nonadapted Fusarium solani f. sp. phaseoli elicits DNA fragmentation of pea in contact with Fusarium solani $\mathrm{f}$. sp. phaseoli and induces a defense response including $P R$ gene expression and phytoalexin accumulation. Ubiquitination of histones and HMG A transcription factor that binds to the $P R$ gene promoter is also associated with nonhost response of pea against Fusarium solani f. sp. phaseoli (Isaac et al. 2009). Therefore, the possibility remains that unexplored plant components are involved in NHR against a wide diversity of pathogens.

\section{Application of NHR for crop improvement.}

NHR is considered a powerful source for durable resistance. Over the past two decades, there have been several attempts to deploy NHR components to improve disease resistance. Introduction of master switches including PRRs and $R$ genes into host plants confers resistance through conserved downstream signaling. Interfamily transfer of Arabidopsis EFR, which recognizes the bacterial PAMP elonglation factor $\mathrm{Tu}$, confers elf18 responsiveness and enhances resistance to a wide-range of bacterial pathogens in transgenic tomato and
$N$. benthamiana (Lacombe et al. 2010). Similarly, N. benthamiana FLS2 was transferred into citrus lacking flg22 perception, resulting in enhanced resistance to citrus canker caused by $X$. citri (Hao et al. 2016). Receptor-like protein ELR from the wild potato Solanum microdontum recognizes several elicitins of the Phytophthora genus and transgenic $S$. tuberosum carrying ELR is resistant to Phytophthora infestans infection (Du et al. 2015). With regard to $R$ gene-mediated resistance, maize Rxol and Arabidopsis $W R R 4$ have been reported to function in other species. Transfer of Rxol into susceptible host rice confers resistance to $X$. oryzae pv. oryzicola carrying the matching effector AvrRxo1 (Zhao et al. 2005). Similarly, WRR4 fully functions in Brassica napus and Brassica juncea against the white rust Albugo candida (Borhan et al. 2010).

In addition, interspecific transfer of metabolic machinery that actively hinder pathogen growth enables host plants to produce foreign antimicrobial compounds from common intermediate molecules. Stilbene synthase, a key enzyme for resveratrol biosynthesis, was identified from grapevine and was then transferred into tobacco (Hain et al. 1993). Transgenic tobacco producing resveratrol shows enhanced resistance to Botrytis cinerea. In the same way, three genes for dhurrin synthesis of Sorghum bicolor were transferred into Arabidopsis, which does not produce dhurrin (Tattersall et al. 2001). Dhurrin accumulation in transgenic Arabidopsis confers resistance to the flea beetle Phylotreta nemorum, which has not encountered dhurrin.

Taken together, these studies have demonstrated the possibility of utilizing nonhost resistance sources across species. Further understanding of NHR genetic basis could broaden the source of disease resistance as well as elucidate the detailed mechanisms of plant resistance.

\section{Conclusion and prospects.}

During the long history of the arms race between hosts and pathogens, plants have evolved unique defense systems (host resistance) against their pathogens, including physical and chemical barriers, PTI activated by surface-localized PRRs, and

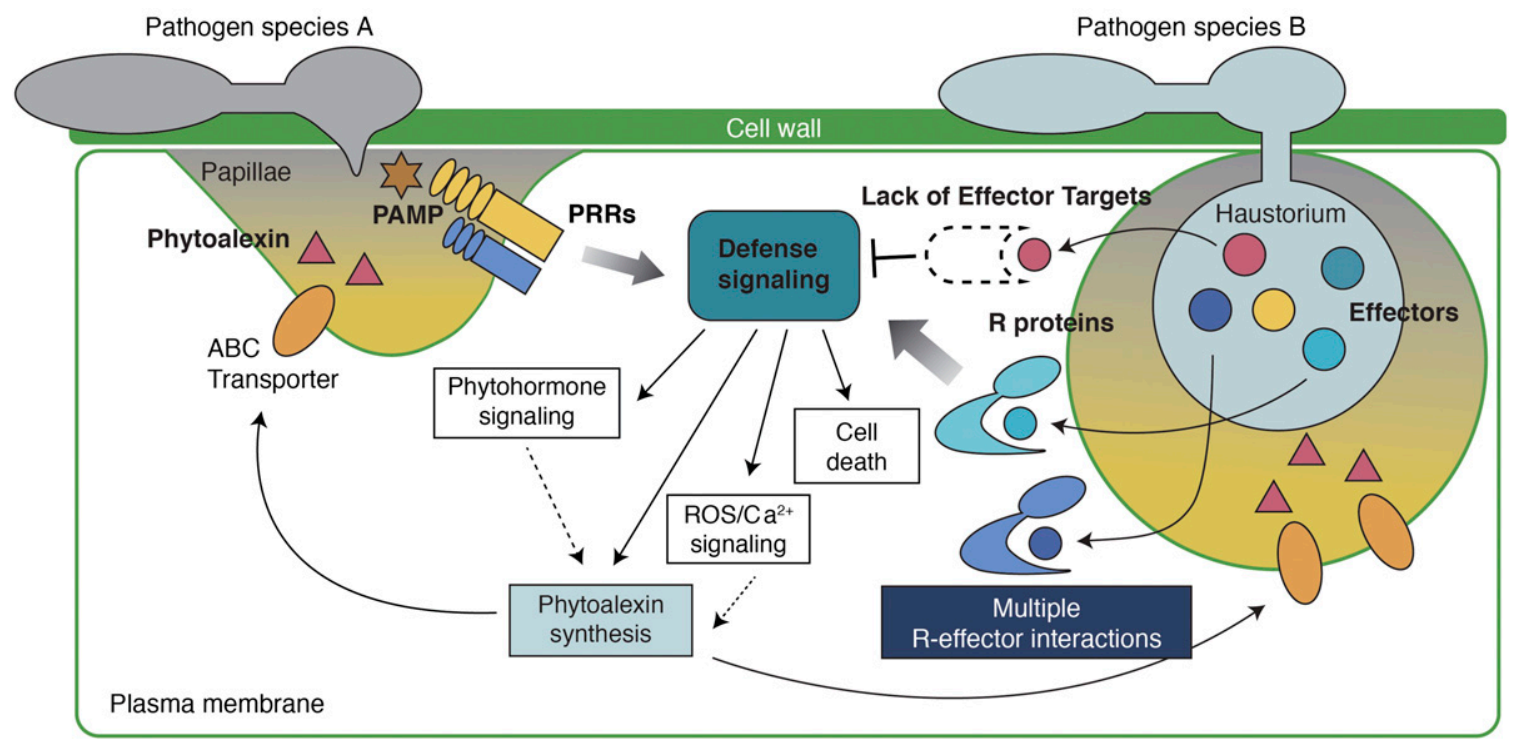

Fig. 1. Mode of action in plant nonhost resistance. Relative contribution of defense components to nonhost resistance (NHR) may vary depending on the pathogen species. Various pathogens cease to grow in nonhost plants due to maldifferentiation of infection structures during preinvasion. In addition, nonhost pattern-recognition receptors (PRRs) trigger defense response via pathogen-associated molecular pattern (PAMP) recognition, which terminates pathogen infection. Conversely, nonadapted pathogens could have not evolved effectors to modulate defense response or nonhost plants could not have effector targets utilized as host factors. Effector-triggered immunity is also a major component of NHR and several evidences support multiple resistance (R) protein-effector interactions. Although NHR largely shares defense signaling components with host resistance, chemical barriers such as phytoalexin have evolved in a speciesspecific manner and play a pivotal role as determinants of host range. 
ETI activated by intracellular NLR immune receptors. However, in nature, most plant species still remain nonhosts for most of pathogens. Then, how could plants establish resistance against previously unencountered pathogens? This critical question remains to be explained. Possibly, plants built up overfull defense potential from the intensive arms race with devastating pathogens over a long period of time. These furnished defense systems of plants could resist a broad spectrum of nonadapted pathogens as the results of so-called "cold war effects." On the pathogen side, they also may have evolved specialized machinery to evade recognition or overcome host defense responses. However, the pathogens may not prepare weapons for battle with unencountered plants.

In this review, we focused on understanding the differences in recognition of nonself and defense mechanisms between hosts and nonhosts at the pre- and postpenetration levels, using all available literatures published during recent decades. Overall, we found the current understanding of NHR mechanisms is not much deviated from our knowledge on host resistance, except for few specific cases (Fig. 1). Several defense factors of host resistance are also involved in NHR, but the relative contribution of the defense factors to determine NHR varies depending on plant or pathosystem.

On that viewpoint, we suggest several topics for further understanding of the NHR mechanism and its implication in crop improvement.

i) Further characterization on the role of PRRs in plant NHR. Most plant genomes contain hundreds of receptor-like protein kinase genes that could be potential PRR candidates, but only a few of them are functionally characterized. High throughput screening using gain- or loss-of-function studies in PRR gene families could provide a number of resistance sources for biotechnological application beyond the species barrier.

ii) Molecular characterization of multiple interactions among effectors of nonadapted pathogens and nonhost plants. A recent study (Lee et al. 2014) strongly supports the idea that ETI caused by multiple interactions between effectors and host factors underpins the NHR of plant species closely related to host plants. Isolation and functional characterization of effector target proteins, including NLRs, could serve as a valuable source of resistance for protecting plants against pathogens in combination with PRRs, as suggested by Du et al. (2015).

iii) Roles of plant secondary metabolites in host range determination. There is lineage-specific evolution of antimicrobial metabolite synthesis in plants, such as isoflavonoids in Leguminosae, indole derivatives in Cruciferae, and sesquiterpenes in Solanaceae plants. Current evidence reveals that preexisting or inducible antimicrobial metabolites have critical roles in host range determination in multiple cases of plant-pathogen interactions, as reviewed above. Revisits and further understanding on the roles of these lineage-specific secondary metabolites in the plant kingdom could provide new insights in NHR from previous knowledge.

NHR is considered the most durable and powerful control measure of plant disease. Further understanding of the critical components exposed in this review will not only extend our knowledge about NHR but, also, provide basic resources for protecting plants against pathogens by combinational biotechnology approaches.

\section{ACKNOWLEDGMENTS}

We thank C. Segonzac for helpful comments and improving our manuscript. We apologize to colleagues whose work could not be highlighted due to space limitations. This work is supported by the Agricultural Genome Center for Next Generation Biogreen21 Program, Rural Development Administration of the Korean Government (Project no. PJ011275012016), and Basic Science Research Program through the National Research Foundation of Korea (NRF) funded by the Ministry of Science, ICT and future Planning (NRF-2015R1A2A1A01002327).

\section{LITERATURE CITED}

Ahuja, I., Kissen, R., and Bones, A. M. 2012. Phytoalexins in defense against pathogens. Trends Plant Sci. 17:73-90.

Allen, C. 1991. Cloning of genes affecting polygalacturonase production in Pseudomonas solanacearum. Mol. Plant-Microbe Interact. 4:147-154.

An, C., and Mou, Z. 2012. Non-host defense response in a novel ArabidopsisXanthomonas citri subsp. citri pathosystem. PLoS One 7:e31130.

Arnold, D. L., Gibbon, M. J., Jackson, R. W., Wood, J. R., Brown, J., Mansfield, J. W., Taylor, J. D., and Vivian, A. 2001. Molecular characterization of avrPphD, a widely-distributed gene from Pseudomonas syringae pv. phaseolicola involved in non-host recognition by pea (Pisum sativum). Physiol. Mol. Plant Pathol. 58:55-62.

Bangham, A. D., and Horne, R. W. 1962. Action of saponin on biological cell membranes. Nature 196:952-953.

Bednarek, P., Piślewska-Bednarek, M., Svatoš, A., Schneider, B., Doubský, J., Mansurova, M., Humphry, M., Consonni, C., Panstruga, R., SanchezVallet, A., Molina, A., and Schulze-Lefert, P. 2009. A glucosinolate metabolism pathway in living plant cells mediates broad-spectrum antifungal defense. Science 323:101-106.

Boller, T., and Felix, G. 2009. A renaissance of elicitors: Perception of microbe-associated molecular patterns and danger signals by patternrecognition receptors. Annu. Rev. Plant Biol. 60:379-406.

Borhan, M. H., Gunn, N., Cooper, A., Gulden, S., Tör, M., Rimmer, S. R., and Holub, E. B. 2008. WRR4 encodes a TIR-NB-LRR protein that confers broad-spectrum white rust resistance in Arabidopsis thaliana to four physiological races of Albugo candida. Mol. Plant-Microbe Interact. 21:757-768

Borhan, M. H., Holub, E. B., Kindrachuk, C., Omidi, M., BozorgmaneshFrad, G., and Rimmer, S. R. 2010. WRR4, a broad-spectrum TIR-NBLRR gene from Arabidopsis thaliana that confers white rust resistance in transgenic oilseed brassica crops. Mol. Plant Pathol. 11:283-291.

Bowyer, P., Clarke, B. R., Lunness, P., Daniels, M. J., and Osbourn, A. E. 1995. Host range of a plant pathogenic fungus determined by a saponin detoxifying enzyme. Science 267:371-374.

Brunner, F., Rosahl, S., Lee, J., Rudd, J. J., Geiler, C., Kauppinen, S., Rasmussen, G., Scheel, D., and Nürnberger, T. 2002. Pep-13, a plant defense-inducing pathogen-associated pattern from Phytophthora transglutaminases. EMBO J. 21:6681-6688.

Campe, R., Langenbach, C., Leissing, F., Popescu, G. V., Popescu, S. C., Goellner, K., Beckers, G. J. M., and Conrath, U. 2016. ABC transporter PEN3/PDR8/ABCG36 interacts with calmodulin that, like PEN3, is required for Arabidopsis nonhost resistance. New Phytol. 209:294-306.

Cheng, Y., Zhang, H., Yao, J., Wang, X., Xu, J., Han, Q., Wei, G., Huang, L., and Kang, Z. 2012. Characterization of non-host resistance in broad bean to the wheat stripe rust pathogen. BMC Plant Biol. 12:96-107.

Chinchilla, D., Zipfel, C., Robatzek, S., Kemmerling, B., Nürnberger, T., Jones, J. D. G., Felix, G., and Boller, T. 2007. A flagellin-induced complex of the receptor FLS2 and BAK1 initiates plant defence. Nature 448:497-500.

Clay, N. K., Adio, A. M., Denoux, C., Jander, G., and Ausubel, F. M. 2009. Glucosinolate metabolites required for an Arabidopsis innate immune response. Science 323:95-101.

Coemans, B., Takahashi, Y., Berberich, T., Ito, A., Kanzaki, H., Matsumura, H., Saitoh, H., Tsuda, S., Kamoun, S., Sági, L., Swennen, R., and Terauchi, R. 2008. High-throughput in planta expression screening identifies an ADPribosylation factor (ARF1) involved in non-host resistance and $R$ genemediated resistance. Mol. Plant Pathol. 9:25-36.

Couto, D., and Zipfel, C. 2016. Regulation of pattern recognition receptor signalling in plants. Nat. Rev. Immunol. 16:537-552.

Crute, I., and Johnson, A. 1976. The genetic relationship between races of Bremiae lactucae and cultivars of Lactuca sativa. Ann. Appl. Biol. 83: 125-137.

Cui, H., Tsuda, K., and Parker, J. E. 2015. Effector-triggered immunity: From pathogen perception to robust defense. Annu. Rev. Plant Biol. 66: 487-511.

Daurelio, L. D., Romero, M. S., Petrocelli, S., Merelo, P., Cortadi, A. A., Talón, M., Tadeo, F. R., and Orellano, E. G. 2013. Characterization of Citrus sinensis transcription factors closely associated with the non-host response to Xanthomonas campestris pv. vesicatoria. J. Plant Physiol. 170:934-942 
De Geyter, N., Gholami, A., Goormachtig, S., and Goossens, A. 2012. Transcriptional machineries in jasmonate-elicited plant secondary metabolism. Trends Plant Sci. 17:349-359.

Delventhal, R., Falter, C., Strugala, R., Zellerhoff, N., and Schaffrath, U. 2014. Ectoparasitic growth of Magnaporthe on barley triggers expression of the putative barley wax biosynthesis gene CYP96B22 which is involved in penetration resistance. BMC Plant Biol. 14:26.

Dixon, R. A. 2001. Natural products and plant disease resistance. Nature 411:843-847.

Dodds, P. N., and Rathjen, J. P. 2010. Plant immunity: Towards an integrated view of plant-pathogen interactions. Nat. Rev. Genet. 11: 539-548.

Du, J., Verzaux, E., Chaparro-Garcia, A., Bijsterbosch, G., Keizer, L. C. P., Zhou, J., Liebrand, T. W. H., Xie, C., Govers, F., Robatzek, S., van der Vossen, E. A. G., Jacobsen, E., Visser, R. G. F., Kamoun, S., and Vleeshouwers, V. G. A. A. 2015. Elicitin recognition confers enhanced resistance to Phytophthora infestans in potato. Nat. Plants 1:15034.

Du Fall, L. A., and Solomon, P. S. 2013. The necrotrophic effector SnToxA induces the synthesis of a novel phytoalexin in wheat. New Phytol. 200: 185-200.

Eichmann, R., Schultheiss, H., Kogel, K. H., and Hückelhoven, R. 2004. The barley apoptosis suppressor homologue BAX inhibitor-1 compromises nonhost penetration resistance of barley to the inappropriate pathogen Blumeria graminis f. sp. tritici. Mol. Plant-Microbe Interact. 17:484-490.

Fan, J., Crooks, C., Creissen, G., Hill, L., Fairhurst, S., Doerner, P., and Lamb, C. 2011. Pseudomonas sax genes overcome aliphatic isothiocyanate-mediated non-host resistance in Arabidopsis. Science 331:1185-1188.

Fan, J., and Doerner, P. 2012. Genetic and molecular basis of nonhost disease resistance: Complex, yes; silver bullet, no. Curr. Opin. Plant Biol. 15:400-406.

Ferrari, S., Galletti, R., Denoux, C., De Lorenzo, G., Ausubel, F. M., and Dewdney, J. 2007. Resistance to Botrytis cinerea induced in Arabidopsis by elicitors is independent of salicylic acid, ethylene, or jasmonate signaling but requires PHYTOALEXIN DEFICIENT3. Plant Physiol. 144:367-379.

Fillingham, A. J., Wood, J., Bevan, J. R., Crute, I. R., Mansfield, J. W., Taylor, J. D., and Vivian, A. 1992. Avirulence genes from Pseudomonas syringae pathovars phaseolicola and pisi confer specificity towards both host and non-host species. Physiol. Mol. Plant Pathol. 40:1-15.

Fink, W., Liefland, M., and Mendgen, K. 1990. Comparison of various stress responses in oat in compatible and nonhost resistant interactions with rust fungi. Physiol. Mol. Plant Pathol. 37:309-321.

Forsyth, A., Mansfield, J. W., Grabov, N., de Torres, M., Sinapidou, E., and Grant, M. R. 2010. Genetic dissection of basal resistance to Pseudomonas syringae pv. phaseolicola in accessions of Arabidopsis. Mol. PlantMicrobe Interact. 23:1545-1552.

Giannakopoulou, A., Schornack, S., Bozkurt, T. O., Haart, D., Ro, D. K., Faraldos, J. A., Kamoun, S., and O’Maille, P. E. 2014. Variation in capsidiol sensitivity between Phytophthora infestans and Phytophthora capsici is consistent with their host range. PLoS One 9:e107462.

Gill, U. S., Lee, S., and Mysore, K. S. 2015. Host versus nonhost resistance: Distinct wars with similar arsenals. Phytopathology 105:580-587.

Graham, T., Kim, J., and Graham, M. 1990. Role of constitutive isoflavone conjugates in the accumulation of glyceollin in soybean infected with Phytophthora megasperma. Mol. Plant-Microbe Interact. 3:157-166.

Grosskinsky, D. K., Naseem, M., Abdelmohsen, U. R., Plickert, N., Engelke, T., Griebel, T., Zeier, J., Novák, O., Strnad, M., Pfeifhofer, H., van der Graaff, E., Simon, U., and Roitsch, T. 2011. Cytokinins mediate resistance against Pseudomonas syringae in tobacco through increased antimicrobial phytoalexin synthesis independent of salicylic acid signaling. Plant Physiol. 157:815-830.

Hadwiger, L. A. 2015. Anatomy of a nonhost disease resistance response of pea to Fusarium solani: PR gene elicitation via DNase, chitosan and chromatin alterations. Front. Plant Sci. 6:373.

Hahlbrock, K., Bednarek, P., Ciolkowski, I., Hamberger, B., Heise, A., Liedgens, H., Logemann, E., Nürnberger, T., Schmelzer, E., Somssich, I. E., and Tan, J. 2003. Non-self recognition, transcriptional reprogramming, and secondary metabolite accumulation during plant/pathogen interactions. Proc. Natl. Acad. Sci. U.S.A. 100 (Suppl 2):14569-14576.

Hain, R., Reif, H.-J., Krause, E., Langebartels, R., Kindl, H., Vornam, B., Wiese, W., Schmelzer, E., Schreier, P. H., Stöcker, R. H., and Stenzel, K. 1993. Disease resistance results from foreign phytoalexin expression in a novel plant. Nature 361:153-156.

Ham, J. H., Kim, M. G., Lee, S. Y., and Mackey, D. 2007. Layered basal defenses underlie non-host resistance of Arabidopsis to Pseudomonas syringae pv. phaseolicola. Plant J. 51:604-616.
Hammerschmidt, R. 1999. PHYTOALEXINS: What Have We Learned After 60 Years? Annu. Rev. Phytopathol. 37:285-306.

Hann, D. R., and Rathjen, J. P. 2007. Early events in the pathogenicity of Pseudomonas syringae on Nicotiana benthamiana. Plant J. 49:607-618.

Hao, G., Pitino, M., Duan, Y., and Stover, E. 2016. Reduced susceptibility to Xanthomonas citri in transgenic citrus expressing the FLS2 receptor from Nicotiana benthamiana. Mol. Plant-Microbe Interact. 29:132-142.

Hayashi, F., Smith, K. D., Ozinsky, A., Hawn, T. R., Yi, E. C., Goodlett, D. R., Eng, J. K., Akira, S., Underhill, D. M., and Aderem, A. 2001. The innate immune response to bacterial flagellin is mediated by Toll-like receptor 5. Nature 410:1099-1103.

He, P., Shan, L., Lin, N.-C., Martin, G. B., Kemmerling, B., Nürnberger, T., and Sheen, J. 2006. Specific bacterial suppressors of MAMP signaling upstream of MAPKKK in Arabidopsis innate immunity. Cell 125: 563-575.

Heath, M. C. 1974. Light and electron microscope studies of the interactions of host and non-host plants with cowpea rust-Uromyces phaseoli var. vignae. Physiol. Plant Pathol. 4:403-414.

Heath, M. C. 1981. A generalized concept of host-parasite specificity. Phytopathology 71:1121-1123.

Heath, M. C. 2000. Nonhost resistance and nonspecific plant defenses. Curr. Opin. Plant Biol. 3:315-319.

Heese, A., Hann, D. R., Gimenez-Ibanez, S., Jones, A. M. E., He, K., Li, J., Schroeder, J. I., Peck, S. C., and Rathjen, J. P. 2007. The receptor-like kinase SERK3/BAK1 is a central regulator of innate immunity in plants. Proc. Natl. Acad. Sci. U.S.A. 104:12217-12222.

Hiruma, K., Fukunaga, S., Bednarek, P., Piślewska-Bednarek, M., Watanabe, S., Narusaka, Y., Shirasu, K., and Takano, Y. 2013. Glutathione and tryptophan metabolism are required for Arabidopsis immunity during the hypersensitive response to hemibiotrophs. Proc. Natl. Acad. Sci. U.S.A. 110:9589-9594.

Hölscher, D., Dhakshinamoorthy, S., Alexandrov, T., Becker, M., Bretschneider, T., Buerkert, A., Crecelius, A. C., De Waele, D., Elsen, A., Heckel, D. G., Heklau, H., Hertweck, C., Kai, M., Knop, K., Krafft C., Maddula, R. K., Matthäus, C., Popp, J., Schneider, B., Schubert, U. S., Sikora, R. A., Svatoš, A., and Swennen, R. L. 2014. Phenalenonetype phytoalexins mediate resistance of banana plants (Musa spp.) to the burrowing nematode Radopholus similis. Proc. Natl. Acad. Sci. U.S.A. 111:105-110.

Hückelhoven, R., Dechert, C., and Kogel, K. H. 2001. Non-host resistance of barley is associated with a hydrogen peroxide burst at sites of attempted penetration by wheat powdery mildew fungus. Mol. Plant Pathol. 2:199-205.

Huffaker, A., Kaplan, F., Vaughan, M. M., Dafoe, N. J., Ni, X., Rocca, J. R., Alborn, H. T., Teal, P. E. A., and Schmelz, E. A. 2011. Novel acidic sesquiterpenoids constitute a dominant class of pathogen-induced phytoalexins in maize. Plant Physiol. 156:2082-2097.

Ichinose, Y., Taguchi, F., Yamamoto, M., Kameyama, M., Atsumi, T., Iwaki, M., Manabe, H., Kumagai, M., Nguyen, Q. T., Nguyen, C. L., Inagaki, Y., Ono, H., Chiku, K., Ishii, T., and Yoshida, M. 2013. Flagellin glycosylation is ubiquitous in a broad range of phytopathogenic bacteria. J. Gen. Plant Pathol. 79:359-365.

Ishiga, Y., Takeuchi, K., Taguchi, F., Inagaki, Y., Toyoda, K., Shiraishi, T., and Ichinose, Y. 2005. Defense responses of Arabidopsis thaliana inoculated with Pseudomonas syringae pv. tabaci wild type and defective mutants for flagellin $(\Delta f l i C)$ and flagellin-glycosylation $(\Delta o r f 1)$. J. Gen. Plant Pathol. 71:302-307.

Ishiga, Y., Uppalapati, S. R., Gill, U. S., Huhman, D., Tang, Y., and Mysore, K. S. 2015. Transcriptomic and metabolomic analyses identify a role for chlorophyll catabolism and phytoalexin during Medicago nonhost resistance against Asian soybean rust. Sci. Rep. 5:13061.

Islam, M., Hashidoko, Y., Ito, T., and Tahara, S. 2004. Interruption of the homing events of phytopathogenic Aphanomyces cochlioides zoospores by secondary metabolites from nonhost Amaranthus gangeticus. J. Pestic. Sci. 29:6-14.

Isaac, J., Hartney, S., Druffel, K., and Hadwiger, L. 2009. The non-host disease resistance response in peas; alterations in phosphorylation and ubiquitination of HMG A and histones H2A/H2B. Plant Sci. 177: 439-449.

Jahnen, W., and Hahlbrock, K. 1988. Cellular localization of nonhost resistance reactions of parsley (Petroselinum crispum) to fungal infection. Planta 173:197-204.

Jensen, M. K., Hagedorn, P. H., de Torres-Zabala, M., Grant, M. R., Rung, J. H., Collinge, D. B., and Lyngkjaer, M. F. 2008. Transcriptional regulation by an NAC (NAM-ATAF1,2-CUC2) transcription factor attenuates ABA signalling for efficient basal defence towards Blumeria graminis f. sp. hordei in Arabidopsis. Plant J. 56:867-880. 
Jeuken, M., and Lindhout, P. 2002. Lactuca saligna, a non-host for lettuce downy mildew (Bremia lactucae), harbors a new race-specific Dm gene and three QTLs for resistance. Theor. Appl. Genet. 105:384-391.

Jones, D. R., Unwin, C. H., and Ward, E. W. B. 1975. Capsidiol induction in pepper fruit during interactions with Phytophthora capsici and Monilinia fructicola. Phytopathology 65:1417-1419.

Jones, J. D. G., and Dangl, J. L. 2006. The plant immune system. Nature 444:323-329.

Kadota, Y., Shirasu, K., and Guerois, R. 2010. NLR sensors meet at the SGT1-HSP90 crossroad. Trends Biochem. Sci. 35:199-207.

Kamoun, S. 2001. Nonhost resistance to Phytophthora: Novel prospects for a classical problem. Curr. Opin. Plant Biol. 4:295-300.

Kamoun, S., van West, P., Vleeshouwers, V. G. A.A., de Groot, K. E., and Govers, F.. 1998. Resistance of nicotiana benthamiana to phytophthora infestans is mediated by the recognition of the elicitor protein INF1. Plant Cell 10:1413-1426.

Kang, L., Li, J., Zhao, T., Xiao, F., Tang, X., Thilmony, R., He, S., and Zhou, J. M. 2003. Interplay of the Arabidopsis nonhost resistance gene NHO1 with bacterial virulence. Proc. Natl. Acad. Sci. U.S.A. 100:35193524.

Kanzaki, H., Saitoh, H., Ito, A., Fujisawa, S., Kamoun, S., Katou, S., Yoshioka, H., and Terauchi, R. 2003. Cytosolic HSP90 and HSP70 are essential components of INF1-mediated hypersensitive response and non-host resistance to Pseudomonas cichorii in Nicotiana benthamiana. Mol. Plant Pathol. 4:383-391.

Kemmerling, B., Schwedt, A., Rodriguez, P., Mazzotta, S., Frank, M., Qamar S. A., Mengiste, T., Betsuyaku, S., Parker, J. E., Müssig, C., Thomma, B. P. H. J., Albrecht, C., de Vries, S. C., Hirt, H., and Nürnberger, T. 2007. The BRI1-associated kinase 1, BAK1, has a brassinolide-independent role in plant cell-death control. Curr. Biol. 17:1116-1122.

Kishi-Kaboshi, M., Okada, K., Kurimoto, L., Murakami, S., Umezawa, T. Shibuya, N., Yamane, H., Miyao, A., Takatsuji, H., Takahashi, A., and Hirochika, H. 2010. A rice fungal MAMP-responsive MAPK cascade regulates metabolic flow to antimicrobial metabolite synthesis. Plant $\mathbf{J}$. 63:599-612.

Kliebenstein, D. J. 2012. Plant defense compounds: Systems approaches to metabolic analysis. Annu. Rev. Phytopathol. 50:155-173.

Knoester, M., Hennig, J., van Loon, L. C., van den Heuvel, J., Bol, J. F., and Linthorst, H. J. 1998. Ethylene-insensitive tobacco lacks nonhost resistance against soil-borne fungi. Proc. Natl. Acad. Sci. U.S.A. 95: 1933-1937.

Kobayashi, D. Y., Tamaki, S. J., and Keen, N. T. 1989. Cloned avirulence genes from the tomato pathogen Pseudomonas syringae pv. tomato confer cultivar specificity on soybean. Proc. Natl. Acad. Sci. U.S.A. 86: 157-161.

Kobayashi, Y., Kobayashi, I., Funaki, Y., Fujimoto, S., Takemoto, T., and Kunoh, H. 1997a. Dynamic reorganization of microfilaments and microtubules is necessary for the expression of non-host resistance in barley coleoptile cells. Plant J. 11:525-537.

Kobayashi, Y., Yamada, M., Kobayashi, I., and Hitoshi, K. 1997b. Actin microfilaments are required for the expression of nonhost resistance in higher plants. Plant Cell Physiol. 38:725-733.

Kroymann, J. 2011. Natural diversity and adaptation in plant secondary metabolism. Curr. Opin. Plant Biol. 14:246-251.

Lacombe, S., Rougon-Cardoso, A., Sherwood, E., Peeters, N., Dahlbeck, D., van Esse, H. P., Smoker, M., Rallapalli, G., Thomma, B. P. H. J., Staskawicz, B., Jones, J. D. G., and Zipfel, C. 2010. Interfamily transfer of a plant pattern-recognition receptor confers broad-spectrum bacterial resistance. Nat. Biotechnol. 28:365-369.

Lee, H. A., Kim, S. Y., Oh, S. K., Yeom, S. I., Kim, S. B., Kim, M. S., Kamoun, S., and Choi, D. 2014. Multiple recognition of RXLR effectors is associated with nonhost resistance of pepper against Phytophthora infestans. New Phytol. 203:926-938.

Lei, J., A Finlayson, S., Salzman, R. A., Shan, L., and Zhu-Salzman, K. 2014. BOTRYTIS-INDUCED KINASE1 modulates Arabidopsis resistance to green peach aphids via PHYTOALEXIN DEFICIENT4. Plant Physiol. 165:1657-1670.

Li, W., Xu, Y. P., Zhang, Z. X., Cao, W. Y., Li, F., Zhou, X., Chen, G. Y., and Cai, X. Z. 2012. Identification of genes required for nonhost resistance to Xanthomonas oryzae pv. oryzae reveals novel signaling components. PLoS One 7:e42796.

Li, X., Lin, H., Zhang, W., Zou, Y., Zhang, J., Tang, X., and Zhou, J. M. 2005. Flagellin induces innate immunity in nonhost interactions that is suppressed by Pseudomonas syringae effectors. Proc. Natl. Acad. Sci. U.S.A. 102:12990-12995.

Lindgren, P. B., Peet, R. C., and Panopoulos, N. J. 1986. Gene cluster of Pseudomonas syringae pv. "phaseolicola" controls pathogenicity of bean plants and hypersensitivity of nonhost plants. J. Bacteriol. 168:512-522.
Lipka, V., Dittgen, J., Bednarek, P., Bhat, R., Wiermer, M., Stein, M., Landtag, J., Brandt, W., Rosahl, S., Scheel, D., Llorente, F., Molina, A., Parker, J., Somerville, S., and Schulze-Lefert, P. 2005. Pre- and postinvasion defenses both contribute to nonhost resistance in Arabidopsis. Science 310:1180-1183.

Liu, H., Chang, Q., Feng, W., Zhang, B., Wu, T., Li, N., Yao, F., Ding, X., and Chu, Z. 2014. Domain dissection of AvrRxo1 for suppressor, avirulence and cytotoxicity functions. PLoS One 9:e113875.

Lu, M., Tang, X., and Zhou, J. M. 2001. Arabidopsis NHO1 is required for general resistance against Pseudomonas bacteria. Plant Cell 13:437-447.

Luna, E., Pastor, V., Robert, J., Flors, V., Mauch-Mani, B., and Ton, J. 2011 Callose deposition: A multifaceted plant defense response. Mol. PlantMicrobe Interact. 24:183-193.

Maeda, K., Houjyou, Y., Komatsu, T., Hori, H., Kodaira, T., and Ishikawa, A. 2009. AGB1 and PMR5 contribute to PEN2-mediated preinvasion resistance to Magnaporthe oryzae in Arabidopsis thaliana. Mol. PlantMicrobe Interact. 22:1331-1340.

Maekawa, T., Kufer, T. A., and Schulze-Lefert, P. 2011. NLR functions in plant and animal immune systems: So far and yet so close. Nat Immunol. 12:817-826.

Mao, G., Meng, X., Liu, Y., Zheng, Z., Chen, Z., and Zhang, S. 2011. Phosphorylation of a WRKY transcription factor by two pathogenresponsive MAPKs drives phytoalexin biosynthesis in Arabidopsis Plant Cell 23:1639-1653.

Matsukawa, M., Shibata, Y., Ohtsu, M., Mizutani, A., Mori, H., Wang, P., Ojika, M., Kawakita, K., and Takemoto, D. 2013. Nicotiana benthamiana calreticulin $3 a$ is required for the ethylene-mediated production of phytoalexins and disease resistance against oomycete pathogen Phytophthora infestans. Mol. Plant-Microbe Interact. 26:880-892.

Mellersh, D. G., and Heath, M. C. 2001. Plasma membrane-cell wall adhesion is required for expression of plant defense responses during fungal penetration. Plant Cell 13:413-424.

Mellersh, D. G., and Heath, M. C. 2003. An investigation into the involvement of defense signaling pathways in components of the nonhost resistance of Arabidopsis thaliana to rust fungi also reveals a model system for studying rust fungal compatibility. Mol. Plant-Microbe Interact. 16:398-404

Mendgen, K. 1978. Attachment of bean rust cell wall material to host and non-host plant tissue. Arch. Microbiol. 119:113-117.

Meng, X., and Zhang, S. 2013. MAPK cascades in plant disease resistance signaling. Annu. Rev. Phytopathol. 51:245-266.

Mishina, T. E., and Zeier, J. 2007. Bacterial non-host resistance: Interactions of Arabidopsis with non-adapted Pseudomonas syringae strains. Physiol. Plant. 131:448-461.

Moreau, M., Degrave, A., Vedel, R., Bitton, F., Patrit, O., Renou, J. P., Barny, M. A., and Fagard, M. 2012. EDS1 contributes to nonhost resistance of Arabidopsis thaliana against Erwinia amylovora. Mol. Plant-Microbe Interact. 25:421-430.

Nagaraj, S., Senthil-Kumar, M., Ramu, V., Wang, K. and Mysore, K. 2015. Plant ribosomal proteins, RPL12 and RPL19, play a role in nonhost disease resistance against bacterial pathogens. Front Plant Sci. 6 Published online. doi:10.3389/fpls.2015.01192.

Narusaka, Y., Narusaka, M., Seki, M., Ishida, J., Shinozaki, K., Nan, Y., Park, P., Shiraishi, T., and Kobayashi, M. 2005. Cytological and molecular analyses of non-host resistance of Arabidopsis thaliana to Alternaria alternata. Mol. Plant Pathol. 6:615-627.

Nasir, K. H., Takahashi, Y., Ito, A., Saitoh, H., Matsumura, H., Kanzaki, H., Shimizu, T., Ito, M., Fujisawa, S., Sharma, P. C., Ohme-Takagi, M. Kamoun, S., and Terauchi, R. 2005. High-throughput in planta expression screening identifies a class II ethylene-responsive element binding factor-like protein that regulates plant cell death and non-host resistance. Plant J. 43:491-505.

Niks, R. E. 1987. Nonhost plant species as donors for resistance to pathogens with narrow host range I. Determination of nonhost status. Euphytica 36:841-852.

Niks, R. E., and Marcel, T. C. 2009. Nonhost and basal resistance: How to explain specificity? New Phytol. 182:817-828

Nürnberger, T., and Brunner, F. 2002. Innate immunity in plants and animals: Emerging parallels between the recognition of general elicitors and pathogen-associated molecular patterns. Curr. Opin. Plant Biol. 5: 318-324.

Nürnberger, T., Nennstiel, D., Jabs, T., Sacks, W. R., Hahlbrock, K., and Scheel, D. 1994. High affinity binding of a fungal oligopeptide elicitor to parsley plasma membranes triggers multiple defense responses. Cell 78:449-460.

O'Brien, J. A., Daudi, A., Butt, V. S., and Bolwell, G. P. 2012. Reactive oxygen species and their role in plant defence and cell wall metabolism. Planta 236:765-779. 
Ogasawara, Y., Kaya, H., Hiraoka, G., Yumoto, F., Kimura, S., Kadota, Y., Hishinuma, H., Senzaki, E., Yamagoe, S., Nagata, K., Nara, M., Suzuki, K., Tanokura, M., and Kuchitsu, K. 2008. Synergistic activation of the Arabidopsis NADPH oxidase AtrbohD by $\mathrm{Ca}^{2+}$ and phosphorylation. J. Biol. Chem. 283:8885-8892.

Ökmen, B., Etalo, D. W., Joosten, M. H. A. J., Bouwmeester, H. J., de Vos, R. C. H., Collemare, J., and de Wit, P. J. G. M. 2013. Detoxification of $\alpha$-tomatine by Cladosporium fulvum is required for full virulence on tomato. New Phytol. 198:1203-1214

Osbourn, A., Clarke, B., Lunness, P., Scott, P., and Daniels, M. J. 1994. An oat species lacking avenacin is susceptible to infection by Gaeumannomyces graminis var. tritici. Physiol. Mol. Plant Pathol. 45:457-467.

Papadopoulou, K., Melton, R. E., Leggett, M., Daniels, M. J., and Osbourn, A. E. 1999. Compromised disease resistance in saponin-deficient plants. Proc. Natl. Acad. Sci. U.S.A. 96:12923-12928.

Pareja-Jaime, Y., Roncero, M. I., and Ruiz-Roldán, M. C. 2008. Tomatinase from Fusarium oxysporum f. sp. lycopersici is required for full virulence on tomato plants. Mol. Plant-Microbe Interact. 21:728-736.

Parker, J. E., Holub, E. B., Frost, L. N., Falk, A., Gunn, N. D., and Daniels, M. J. 1996. Characterization of eds1, a mutation in Arabidopsis suppressing resistance to Peronospora parasitica specified by several different RPP genes. Plant Cell 8:2033-2046.

Peart, J. R., Lu, R., Sadanandom, A., Malcuit, I., Moffett, P., Brice, D. C., Schauser, L., Jaggard, D. A. W., Xiao, S., Coleman, M. J., Dow, M., Jones, J. D. G., Shirasu, K., and Baulcombe, D. C. 2002. Ubiquitin ligase-associated protein SGT1 is required for host and nonhost disease resistance in plants. Proc. Natl. Acad. Sci. U.S.A. 99: 10865-10869.

Perumalla, C. J., and Heath, M. C. 1989. Effect of callose inhibition on haustorium formation by the cowpea rust fungus in the non-host, bean plant. Physiol. Mol. Plant Pathol. 35:375-382.

Pinosa, F., Buhot, N., Kwaaitaal, M., Fahlberg, P., Thordal-Christensen, H., Ellerström, M., and Andersson, M. X. 2013. Arabidopsis phospholipase $\mathrm{d} \delta$ is involved in basal defense and nonhost resistance to powdery mildew fungi. Plant Physiol. 163:896-906.

Podila, G. K., Rogers, L. M., and Kolattukudy, P. E. 1993. Chemical signals from avocado surface wax trigger germination and appressorium formation in Colletotrichum gloeosporioides. Plant Physiol. 103: 267-272.

Raaymakers, T. M. and Van den Ackerveken, G.. 2016. Extracellular recognition of oomycetes during biotrophic infection of plants. Front Plant Sci. 7. Published online. doi:10.3389/fpls.2016.00906.

Rahman, H., Yang, J., Xu, Y., Munyampundu, J. and Cai, X. 2016. Phylogeny of plant CAMTAs and role of AtCAMTAs in nonhost resistance to Xanthomonas oryzae pv. oryzae. Front Plant Sci. 7. Published online. doi: doi:10.3389/fpls.2016.00177.

Ranf, S., Eschen-Lippold, L., Pecher, P., Lee, J., and Scheel, D. 2011. Interplay between calcium signalling and early signalling elements during defence responses to microbe- or damage-associated molecular patterns. Plant J. 68:100-113.

Ren, D., Liu, Y., Yang, K. Y., Han, L., Mao, G., Glazebrook, J., and Zhang, S. 2008. A fungal-responsive MAPK cascade regulates phytoalexin biosynthesis in Arabidopsis. Proc. Natl. Acad. Sci. U.S.A. 105:56385643 .

Robert-Seilaniantz, A., MacLean, D., Jikumaru, Y., Hill, L., Yamaguchi, S., Kamiya, Y., and Jones, J. D. G. 2011. The microRNA miR393 re-directs secondary metabolite biosynthesis away from camalexin and towards glucosinolates. Plant J. 67:218-231.

Roddick, J. 1976. Intracellular distribution of the steroidal glycoalkaloid $\alpha$-tomatine in Lycopersicon esculentum fruit. Phytochemistry 15:475-477.

Rojas, A. M., Fuentes, G., Rausell, A., and Valencia, A. 2012a. The Ras protein superfamily: Evolutionary tree and role of conserved amino acids. J. Cell Biol. 196:189-201.

Rojas, C. M., Senthil-Kumar, M., Wang, K., Ryu, C. M., Kaundal, A., and Mysore, K. S. 2012b. Glycolate oxidase modulates reactive oxygen species-mediated signal transduction during nonhost resistance in Nicotiana benthamiana and Arabidopsis. Plant Cell 24:336-352.

Roldán-Arjona, T., Pérez-Espinosa, A., and Ruiz-Rubio, M. 1999. Tomatinase from Fusarium oxysporum f. sp. lycopersici defines a new class of saponinases. Mol. Plant-Microbe Interact. 12:852-861.

Roux, M., Schwessinger, B., Albrecht, C., Chinchilla, D., Jones, A., Holton, N., Malinovsky, F. G., Tör, M., de Vries, S., and Zipfel, C. 2011. The Arabidopsis leucine-rich repeat receptor-like kinases BAK1/SERK3 and BKK1/SERK4 are required for innate immunity to hemibiotrophic and biotrophic pathogens. Plant Cell 23:2440-2455.

Sanchez-Vallet, A., Ramos, B., Bednarek, P., López, G., PiślewskaBednarek, M., Schulze-Lefert, P., and Molina, A. 2010. Tryptophanderived secondary metabolites in Arabidopsis thaliana confer non-host resistance to necrotrophic Plectosphaerella cucumerina fungi. Plant J. 63:115-127.

Sandrock, R. W., and VanEtten, H. D. 1998. Fungal sensitivity to and enzymatic degradation of the phytoanticipin $\alpha$-tomatine. Phytopathology 88:137-143.

Schulz, G. and Sander, H. 1957. [Cholesterol tomatide: A new molecular formation for the analysis and preparative extraction of steroids]. HoppeSeyler's Zeitschrift für Physiol. 308:122-126.

Schulze-Lefert, P., and Panstruga, R. 2011. A molecular evolutionary concept connecting nonhost resistance, pathogen host range, and pathogen speciation. Trends Plant Sci. 16:117-125.

Segonzac, C., and Zipfel, C. 2011. Activation of plant pattern-recognition receptors by bacteria. Curr. Opin. Microbiol. 14:54-61.

Sharma, P. C., Ito, A., Shimizu, T., Terauchi, R., Kamoun, S., and Saitoh, H. 2003. Virus-induced silencing of WIPK and SIPK genes reduces resistance to a bacterial pathogen, but has no effect on the INF1induced hypersensitive response (HR) in Nicotiana benthamiana. Mol. Genet. Genomics 269:583-591.

Shimada, C., Lipka, V., O’Connell, R., Okuno, T., Schulze-Lefert, P., and Takano, Y. 2006. Nonhost resistance in Arabidopsis-Colletotrichum interactions acts at the cell periphery and requires actin filament function. Mol. Plant-Microbe Interact. 19:270-279.

Shimizu, R., Taguchi, F., Marutani, M., Mukaihara, T., Inagaki, Y., Toyoda, K., Shiraishi, T., and Ichinose, Y. 2003. The DeltafliD mutant of Pseudomonas syringae pv. tabaci, which secretes flagellin monomers, induces a strong hypersensitive reaction (HR) in non-host tomato cells. Mol. Genet. Genomics 269:21-30.

Sohn, K. H., Saucet, S. B., Clarke, C. R., Vinatzer, B. A., O’Brien, H. E., Guttman, D. S., and Jones, J. D. 2012. HopAS1 recognition significantly contributes to Arabidopsis nonhost resistance to Pseudomonas syringae pathogens. New Phytol. 193:58-66.

Stam, R., Mantelin, S., McLellan, H., and Thilliez, G. 2014. The role of effectors in nonhost resistance to filamentous plant pathogens. Front. Plant Sci. 5:582.

Stassen, J. H. M., den Boer, E., Vergeer, P. W. J., Andel, A., Ellendorff, U., Pelgrom, K., Pel, M., Schut, J., Zonneveld, O., Jeuken, M. J. W., and Van den Ackerveken, G. 2013. Specific in planta recognition of two GKLR proteins of the downy mildew Bremia lactucae revealed in a large effector screen in lettuce. Mol. Plant-Microbe Interact. 26:1259-1270.

Taguchi, F., Shibata, S., Suzuki, T., Ogawa, Y., Aizawa, S., Takeuchi, K., and Ichinose, Y. 2008. Effects of glycosylation on swimming ability and flagellar polymorphic transformation in Pseudomonas syringae pv. tabaci 6605. J. Bacteriol. 190:764-768.

Taguchi, F., Shimizu, R., Inagaki, Y., Toyoda, K., Shiraishi, T., and Ichinose, Y. 2003. Post-translational modification of flagellin determines the specificity of HR induction. Plant Cell Physiol. 44:342-349.

Taguchi, F., Suzuki, T., Takeuchi, K., Inagaki, Y., Toyoda, K., Shiraishi, T., and Ichinose, Y. 2009. Glycosylation of flagellin from Pseudomonas syringae pv. tabaci 6605 contributes to evasion of host tobacco plant surveillance system. Physiol. Mol. Plant Pathol. 74:11-17.

Takahashi, Y., Berberich, T., Kanzaki, H., Matsumura, H., Saitoh, H., Kusano, T., and Terauchi, R. 2009. Serine palmitoyltransferase, the first step enzyme in sphingolipid biosynthesis, is involved in nonhost resistance. Mol. Plant-Microbe Interact. 22:31-38.

Takahashi, Y., Nasir, K. H., Ito, A., Kanzaki, H., Matsumura, H., Saitoh, H., Fujisawa, S., Kamoun, S., and Terauchi, R. 2007. A high-throughput screen of cell-death-inducing factors in Nicotiana benthamiana identifies a novel MAPKK that mediates INF1-induced cell death signaling and non-host resistance to Pseudomonas cichorii. Plant J. 49:1030-1040.

Takemoto, D., Jones, D. A., and Hardham, A. R. 2003. GFP-tagging of cell components reveals the dynamics of subcellular re-organization in response to infection of Arabidopsis by oomycete pathogens. Plant J. 33: 775-792.

Takeuchi, K., Taguchi, F., Inagaki, Y., Toyoda, K., Shiraishi, T., and Ichinose, Y. 2003. Flagellin glycosylation island in Pseudomonas syringae pv. glycinea and its role in host specificity. J. Bacteriol. 185: 6658-6665.

Tattersall, D. B., Bak, S., Jones, P. R., Olsen, C. E., Nielsen, J. K., Hansen, M. L., Høj, P. B., and Møller, B. L. 2001. Resistance to an herbivore through engineered cyanogenic glucoside synthesis. Science 293:1826-1828.

Trujillo, M., Kogel, K. H., and Hückelhoven, R. 2004. Superoxide and hydrogen peroxide play different roles in the nonhost interaction of barley and wheat with inappropriate formae speciales of Blumeria graminis. Mol. Plant-Microbe Interact. 17:304-312.

Tsuba, M., Katagiri, C., Takeuchi, Y., Takada, Y., and Yamaoka, N. 2002. Chemical factors of the leaf surface involved in the morphogenesis of Blumeria graminis. Physiol. Mol. Plant Pathol. 60:51-57. 
Tsuda, K., and Katagiri, F. 2010. Comparing signaling mechanisms engaged in pattern-triggered and effector-triggered immunity. Curr. Opin. Plant Biol. 13:459-465.

Tucker, S. L., and Talbot, N. J. 2001. Surface attachment and prepenetration stage development by plant pathogenic fungi. Annu. Rev. Phytopathol. 39:385-417.

Umemoto, N., Kakitani, M., Iwamatsu, A., Yoshikawa, M., Yamaoka, N., and Ishida, I. 1997. The structure and function of a soybean $\beta$-glucanelicitor-binding protein. Proc. Natl. Acad. Sci. U.S.A. 94:1029-1034.

Uppalapati, S. R., Ishiga, Y., Doraiswamy, V., Bedair, M., Mittal, S., Chen, J., Nakashima, J., Tang, Y., Tadege, M., Ratet, P., Chen, R., Schultheiss, H., and Mysore, K. S. 2012. Loss of abaxial leaf epicuticular wax in Medicago truncatula irg1/palm1 mutants results in reduced spore differentiation of anthracnose and nonhost rust pathogens. Plant Cell 24:353-370.

VanEtten, H. D., Mansfield, J. W., Bailey, J. A., and Farmer, E. E. 1994. Two classes of plant antibiotics: Phytoalexins versus "phytoanticipins". Plant Cell 6:1191-1192.

Vega-Arreguín, J. C., Jalloh, A., Bos, J. I., and Moffett, P. 2014. Recognition of an Avr3a homologue plays a major role in mediating nonhost resistance to Phytophthora capsici in Nicotiana species. Mol. Plant-Microbe Interact. 27:770-780.

Wang, X., Basnayake, B. M. V. S., Zhang, H., Li, G., Li, W., Virk, N., Mengiste, T., and Song, F. 2009. The Arabidopsis ATAF1, a NAC transcription factor, is a negative regulator of defense responses against necrotrophic fungal and bacterial pathogens. Mol. Plant-Microbe Interact. 22:1227-1238.

Wei, C. F., Kvitko, B. H., Shimizu, R., Crabill, E., Alfano, J. R., Lin, N. C., Martin, G. B., Huang, H. C., and Collmer, A. 2007. A Pseudomonas syringae pv. tomato DC3000 mutant lacking the type III effector HopQ1-1 is able to cause disease in the model plant Nicotiana benthamiana. Plant J. 51:32-46.

Whalen, M. C., Stall, R. E., and Staskawicz, B. J. 1988. Characterization of a gene from a tomato pathogen determining hypersensitive resistance in non-host species and genetic analysis of this resistance in bean. Proc. Natl. Acad. Sci. U.S.A. 85:6743-6747.

Wroblewski, T., Caldwell, K. S., Piskurewicz, U., Cavanaugh, K. A., Xu, H., Kozik, A., Ochoa, O., McHale, L. K., Lahre, K., Jelenska, J., Castillo, J. A., Blumenthal, D., Vinatzer, B. A., Greenberg, J. T., and Michelmore, R. W. 2009. Comparative large-scale analysis of interactions between several crop species and the effector repertoires from multiple pathovars of Pseudomonas and Ralstonia. Plant Physiol. 150:1733-1749.
Yun, B. W., Atkinson, H. A., Gaborit, C., Greenland, A., Read, N. D., Pallas, J. A., and Loake, G. J. 2003. Loss of actin cytoskeletal function and EDS1 activity, in combination, severely compromises non-host resistance in Arabidopsis against wheat powdery mildew. Plant J. 34: 768-777.

Zellerhoff, N., Himmelbach, A., Dong, W., Bieri, S., Schaffrath, U., and Schweizer, P. 2010. Nonhost resistance of barley to different fungal pathogens is associated with largely distinct, quantitative transcriptional responses. Plant Physiol. 152:2053-2066.

Zhang, H., Wang, C., Cheng, Y., Wang, X., Li, F., Han, Q., Xu, J., Chen, X., Huang, L., Wei, G., and Kang, Z. 2011. Histological and molecular studies of the non-host interaction between wheat and Uromyces fabae. Planta 234:979-991.

Zhang, J., Shao, F., Li, Y., Cui, H., Chen, L., Li, H., Zou, Y., Long, C., Lan, L., Chai, J., Chen, S., Tang, X., and Zhou, J. M. 2007. A Pseudomonas syringae effector inactivates MAPKs to suppress PAMP-induced immunity in plants. Cell Host Microbe 1:175-185.

Zhao, B., Ardales, E. Y., Raymundo, A., Bai, J., Trick, H. N., Leach, J. E., and Hulbert, S. H. 2004b. The avrRxol gene from the rice pathogen Xanthomonas oryzae pv. oryzicola confers a nonhost defense reaction on maize with resistance gene Rxo1. Mol. Plant-Microbe Interact. 17: 771-779.

Zhao, B., Lin, X., Poland, J., Trick, H., Leach, J., and Hulbert, S. 2005. A maize resistance gene functions against bacterial streak disease in rice. Proc. Natl. Acad. Sci. U.S.A. 102:15383-15388.

Zhao, B. Y., Ardales, E., Brasset, E., Claflin, L. E., Leach, J. E., and Hulbert, S. H. 2004a. The Rxol/ Rbal locus of maize controls resistance reactions to pathogenic and non-host bacteria. Theor. Appl. Genet. 109:71-79.

Zimmerli, L., Stein, M., Lipka, V., Schulze-Lefert, P., and Somerville, S. 2004. Host and non-host pathogens elicit different jasmonate/ethylene responses in Arabidopsis. Plant J. 40:633-646.

Zipfel, C. 2009. Early molecular events in PAMP-triggered immunity. Curr. Opin. Plant Biol. 12:414-420.

Zipfel, C., Robatzek, S., Navarro, L., Oakeley, E. J., Jones, J. D. G., Felix, G., and Boller, T. 2004. Bacterial disease resistance in Arabidopsis through flagellin perception. Nature 428:764-767.

Zurbriggen, M. D., Carrillo, N., Tognetti, V. B., Melzer, M., Peisker, M., Hause, B., and Hajirezaei, M. R. 2009. Chloroplast-generated reactive oxygen species play a major role in localized cell death during the nonhost interaction between tobacco and Xanthomonas campestris pv. vesicatoria. Plant J. 60:962-973. 